\title{
MASKULINITAS BARU DALAM IKLAN KOSMETIK KOREA: ETUDE HOUSEDAN TONYMOLY
}

\section{NEW MASCULINITY IN KOREAN COSMETIC ADVERTISING: ETUDE ANDTONYMOLY}

\author{
Ezzah Fathinah, Aquarini Priyatna, Muhamad Adji \\ Fakultas Ilmu Budaya, UNPAD \\ Jl. Raya Bandung -Sumedang Km. 21, Hegarmanah, Jatinangor, Kabupaten Sumedang \\ Alamat e-mail: ichbinezzah@gmail.com
}

\begin{abstract}
Abstrak
Penelitian ini membahas maskulinitas dalam iklan produk kecantikan korea Etude House dan TonyMoly. Iklan-iklan ini menampilkan laki-laki cantik yang merawat diri dan mementingkan penampilan. Laki-laki tersebut ditampilkan ramah dan membawa atribusi 'cantik', yang digemari serta diidolakan beberapa kelompok perempuan tertentu di Indonesia. Hal ini sangat berbeda dengan konsep maskulinitas yang menjadi standar ideal konstruksi sosial budaya di Indonesia, yang cenderung kaku, kuat dan otoriter. Artikel ini berargumentasi bahwa kecenderungan itu juga dipengaruhi media, salah satunya iklan, sehingga representasi serta opini publik mengenai maskulinitas hegemonik terrekonstruksi. Penelitian ini menggunakan pendekatan semiotika Barthes, dengan mengkaji tanda-tanda pada iklan di dalam data tekstual mau pun visual. Dari data yang dianalisis, ditemukan adanya maskulinitas baru yang bersifat lebih cair, di mana lakilaki tidak harus mengikuti standar ideal maskulinitas hegemonik.
\end{abstract}

Kata kunci: maskulinitas, laki-laki, iklan, kosmetik.

\begin{abstract}
This research discusses masculinity in the advertisement of beauty products of Korean Etude House and TonyMoly. These ads feature beautiful men who look after themselves and concerned with appearances. The man is shown friendly and carries the 'beauty' attribution, which is liked and idolized by certain groups of women in Indonesia. This is very different from the concept of masculinity which becomes the ideal standard of socio-cultural construction in Indonesia, which tends to be rigid, strong and authoritarian. This article argues that the trend is also influenced by the media, one of it is advertising, and hence the representation and public opinion about hegemonic masculinity is reconstructed. This research uses Barthes's semiotic approach through examining the signs on the ads in textual data as well as visual. From the data analyzed, new masculinity is found that is more lithe, in which men do not have to follow the ideal standard of hegemonic masculinity.
\end{abstract}

Keywords: masculinity, men, advertising, cosmetics.

\section{A. PENDAHULUAN}

Indonesia, yang merupakan salah satu target pasar budaya korea (korean wave), turut mendapat pengaruh dari representasi ketampanan laki-laki ramah yang juga membawa atribusi 'cantik', yang digemari serta diidolakan beberapa kelompok perempuan tertentu di Indonesia.

Korean Wave merupakan istilah yang diberikan untuk tersebarnya budaya populer Korea secara global di berbagai negara di dunia. Korean Wave mencangkup beberapa aspek hiburan seperti drama Korea (K-Drama), musik 
Korea (K-pop), makanan khas Korea, pakaian khas Korea, serta produk-produk dari Korea (Wardani, 2013). Pada tahun 2002, drama Korea (K-drama) yang berjudul Endless Love mulai merambah industri massa Indonesia. Hal tersebut menjadi pemicu masuknya hegemoni kebudayaan Korea di Indonesia yang diikuti drama-drama Korea yang dapat dinikmati melalui teknologi media streaming, sehingga sangat mudah untuk mengakses drama Korea lewat internet. Di dalam drama Korea, ditampilkan unsurunsur kebudayaan seperti kebiasaan, makanan, gaya hidup masyarakat Korea, yang kemudian menjadi nilai jual terhadap produk-produk dan brand-brand buatan Korea, salah satunya produk kecantikan yang tersebar melalui iklan-iklan di media sosial, sehingga menjadi komoditas populer di Indonesia.

Beberapa iklan-iklan produk kecantikan Korea, menggunakan model laki-laki sebagai bintang iklannya. Lakilaki yang dipilih kebanyakan adalah para anggota boyband atau artis drama Korea yang memiliki banyak penggemar. Kemudian laki-laki cantik yang ditampilkan iklan produk kecantikan menunjukkan adanya rekonstruksi gender. Butler (1990: 125) menyatakan bahwa gender adalah sebuah performavitas yang di dalamnya terdapat aturan bahwa seseorang harus berlaku sesuai atribusi gender yang telah dilekatkan padanya. Hal ini menunjukkan bahwa laki-laki harus maskulin dan perempuan harus feminin. Laki-laki yang terdapat pada iklan produk kecantikan ini ditampilkan maskulin juga feminin, sehingga menampilkan kode-kode baru maskulinitas.

Kemudian, sosok laki-laki yang ditampilkan dalam iklan produk kecantikan tersebut menyodorkan berbagai citra maskulinitas baru sehingga menarik konsumen laki-laki untuk tampil cantik. Hal ini menunjukkan bagaimana peran media dalam menghegemoni suatu massa. Menurut Hall (1997), ideologi meresap dan bekerja dalam 'teks' media (massa) yang mengonstruksi pembentukan realitas dalam kehidupan sehari-hari. Hal ini menunjukkan bahwa media memiliki kemampuan untuk melakukan hegemoni kebudayaan terhadap suatu negara. Hal tersebut nampak dari bagaimana budaya Korea (Korean Wave) masuk dan diterima oleh negara Indonesia serta menjadi target pasar produk kecantikan Korea.

Iklan sebagai ujung tombak promosi produk. Menurut Wright sebagaimana dikutip oleh Liliweri (1992: 20), iklan merupakan hal yang dapat dilihat, didengar dan ditonton di mana saja, baik di televisi, radio dan media cetak seperti surat kabar dan majalah. Iklan mempunyai kemampuan dalam menembus situasi dan kondisi yang awalnya sulit dijangkau. Iklan bersifat materialistik atau menyebabkan orang tergantung pada produk.

Selain itu, iklan juga berfungsi sebagai alat menyampaikan suatu ideologi. Sebagaimana disebutkan Piliang (1998), iklan mengonstruksi masyarakat menjadi kelompok-kelompok gaya hidup yang pola kehidupannya diatur berdasarkan tema, citra dan makna simbolik tertentu. Dengan kata lain, iklan dianggap efektif dalam mempengaruhi persepsi seseorang serta ideologi yang dianut seseorang. Misalnya, dengan melejitnya kepopuleran aktor dari suatu karakter laki-laki dalam drama populer, maka produk-produk kecantikan Korea menggunakan aktor tersebut sebagai nilai jual suatu produk, salah satuya produk kosmetik. Dalam iklan-iklan kosmetik menampilkan sosok model lakilaki tampan, cantik, putih, berbibir merah, berkulit mulus dan modis dalam berpakaian. Gaya berpakaian, rias wajah, tingkah dan gestur model tersebut banyak ditiru. Sehingga iklan-iklan yang menampilkan sosok laki-laki tersebut menjadi teks yang merepresentasikan bentuk maskulinitas serta citra ideal bagi laki-laki.

Maskulinitas dapat didefinisikan secara sosial sebagai cara untuk menjadi seorang laki-laki (Tuncay, 2012: 313). 
Sedangkan maskulinitas hegemonik adalah bentuk karakter maskulin yang- diidealkan secara kultural (Connel, 1990: 83). Sehingga terjadi keseragaman konsep maskulinitas tertentu yang menjadi standar laki-laki untuk menjadi maskulin. Kemudian muncul konsep maskulinitas tradisional menganggap tinggi nilai-nilai kekuatan, kekuasaan, ketabahan, aksi, kendali, kemandirian, kepuasan diri, kesetiakawanan laki-laki dan pekerjaan (Barker, 2000). Hal ini sangat bertolak belakang dengan konsep maskulinitas modern. Konsep maskulinitas modern digambarkan dengan laki-laki yang lebih perhatian, sensitif, ekspresif dan bersedia melakukan pekerjaan domestik (Beynon, 2002). Ada pergeseran bentuk maskulinitas hegemonik yang timbul karena laki-laki kemudian mempunyai keberanian mengkritisi wacana kelelakiannya bagi mereka yang merasa terbebani dengan tradisi maskulinitas tradisional. Ketika maskulinitas tradisional tidak lagi menjadi standar untuk menjadi laki-laki, maskulinitas modern menjadi maskulinitas yang hegemonik, yang diidealkan. Hal tersebut dipengaruhi oleh promosi iklan menjual berbagai citra yang menelikung ikon-ikon maskulinitas tradisional (Mort, dikutip Chapmann, 1988). Butler (1990) memaparkan bahwa tubuh melakukan tindakan gender tertentu yang diulang, diperbaiki dan diperkuat seiring berjalanannya waktu. Dengan maraknya Korean Wave, representasi laki-laki Korea yang membawa atribusi cantik memunculkan identitas gender baru dalam maskulinitas. Hal ini menunjukkan bahwa konsep maskulinitas merupakan bentuk konstruksi sosial kultural yang dapat berubah dan bersifat dinamis. Mort sebagaimana dikutip Chapman (1988), Maskulinitas bukan entitas yang statis dan tidak berubah, melainkan sebagai proses.

Berbicara mengenai maskulinitas tentu saja tak bisa lepas dari pembicaraan mengenai gender. Secara umum, gender berbeda dengan jenis kelamin. Jenis kelamin dianggap sebagai konstruksi biologis yang dibawa setiap individu sesuai dengan kodratnya sejak lahir. Konstruksi ini tidak pernah berubah, lakilaki dan perempuan. Sedangkan gender adalah kontruksi sosial dan budaya. Menurut Ostergaard (1997: 26), konsep gender memungkinkan untuk membedakan secara biologis, perbedaan seksual antara perempuan dan laki-laki dari perbedaan budaya ditentukan antara peran yang diberikan atau dilakukan oleh setiap perempuan dan setiap laki-laki dalam suatu masyarakat tertentu. Hal tersebut menjelaskan bahwa setiap perempuan harus bertindak feminin dan laki-laki harus bertindak maskulin.

Konsep maskulinitas dalam literatur berbahasa Inggris sering kali didefinisikan dengan kata jamak, yakni masculinities. Hal ini dikarenakan pengertian tentang maskulinitas berbeda-beda di setiap tempat dan kebudayaannya. Budaya yang berbeda dan periode serta sejarah yang berbeda akan mengonstruksi konsep gender yang berbeda pula (Connel, 2000: 10).

Beynon (2002: 2) menambahkan, maskulinitas bukan bagian dari genetik laki-laki yang dibawa ketika mereka dilahirkan, melainkan sesuatu yang terbentuk dan teralkulturisasi oleh perilaku sosial, mereka mempelajari dan menirunya dengan cara yang sesuai.

Definisi maskulinitas yang beragam tidak duduk berdampingan, ada ketentuan sosial di dalamnya. Maskulinitas pun berhubungan dengan hierarki, di mana dalam suatu masyarakat terdapat maskulinitas dominan (hegemonik) dan maskulinitas yang terpinggirkan (Connel dan Connel, 2000: 10). Adanya hierarki ini, bukan hanya antara laki-laki dan lakilaki, namun laki-laki dan perempuan. Hal tersebut ditemukan hampir di semua kebudayaan. Hal tersebut menunjukkan bahwa maskulinitas baru yang terdapat unsur feminitas di dalamnya bukan lah yang bersifat hegemonik.

Laki-laki hegemonik adalah laki-laki yang kaku, kuat, sukses, kompeten, serta otoriter yang mendapatkan reputasinya dari 
tempat ia bekerja dan meraih harga dirinya di area publik (Feasey, 2008). Dengan kata lain, konsep maskulinitas dominan adalah laki-laki yang memiliki kekuatan dan berkuasa. Maskulinitas dominan ini biasanya bukan lah yang paling nyaman untuk dijalankan. Hal tersebut tidak mengurangi kredibilitas sebagai maskulinitas standar yang diharapkan oleh laki-laki (MacKinnon dikutip oleh Feasey, 2008: 3).

Carrigan dkk sebagaimana dikutip oleh Feasey (2008) menjelaskan bahwa yang menjadi fokus utama dalam maskulinitas hegemonik ini adalah lakilaki mendapat keuntungan dari dominasinya atas kaum perempuan.

Dalam papan iklan, televisi, majalah dan surat kabar mulai terkonstruksi citra laki-laki baru. Laki-laki baru digambarkan dengan laki-laki yang lebih sensitif, ekspresif, perhatian dan bersedia melakukan pekerjaan domestik (Cornwall dan Lindisfarne, 1994).

Melalui keinginan pasar, iklan-iklan produk kosmetik Korea Etude House dan TonyMoly menampilkan tubuh laki-laki. Hal ini menjadi sebuah kesepakatan masyarakat akan definisi maskulinitas yang terkonstruksi dengan terjualnya produk dari iklan tersebut. Kemudian iklan tersebut menjadi teks yang mengandung ideologi yang berkaitan dengan konstruksi gender mengenai maskulinitas. Melalui representasi visual dalam iklan-iklan tersebut, penelitian ini bertujuan untuk memaparkan bagaimana maskulinitas baru meresistensi nilai-nilai maskulinitas hegemonik.

\section{B. METODE PENELITIAN}

penelitian ini adalah metode kualitatif. Karena pendekatan kualitatif mempelajari produksi makna sebagai proses yang dikontekstualisasikan dan diintegrasikan dalam praktik sosial dan kultural yang lebih luas. Data yang diambil berupa data visual yang terdapat dalam iklan Etude House dan TonyMoly. Penelitian ini merupakan analisis tekstual dengan menggunakan teori dan model analisis untuk mengkaji iklan. Data visual yang dipilih akan dianalisis dengan menggunakan beberapa teori dan model analisis. Dalam pengaplikasiannya, untuk menganalisis representasi dan video iklan digunakan teori milik Stuart Hall dan teori semiotika Barthes.

Pengertian dari representasi adalah produksi makna mengenai konsep pemikiran kita yang disampaikan melalui bahasa (Hall, 1997: 17). Bahasa merupakan faktor utama dalam mengonstruksi makna. Yang dimaksud dengan bahasa bukan hanya berupa bahasa tulis dan lisan, tetapi juga tanda (sign) dan simbol (symbols) yang biasa digunakan, seperti gambar (foto, lukisan, dll), musik yang merepresentasikan pemikiran, ide, maupun perasaan yang kita miliki terhadap orang lain.

Gambar-gambar pada iklan yang diteliti akan diuraikan maknanya dengan menggunakan teori second order signification (signifikasi dua tahap) Barthes yaitu denotasi dan konotasi. Denotasi adalah makna primer, sedangkan konotasi adalah makna sekunder. Lebih jelasnya, konotasi adalah pengembangan segi petanda (makna atau isi suatu tanda) oleh pemakai tanda sesuai dengan sudut pandangnya (Hoed, 2011: 5). Konotasi yang sudah menguasai masyarakat akan menjadi mitos. Mitos kemudian dianggap menjadi satu hal yang wajar dalam keseharian.

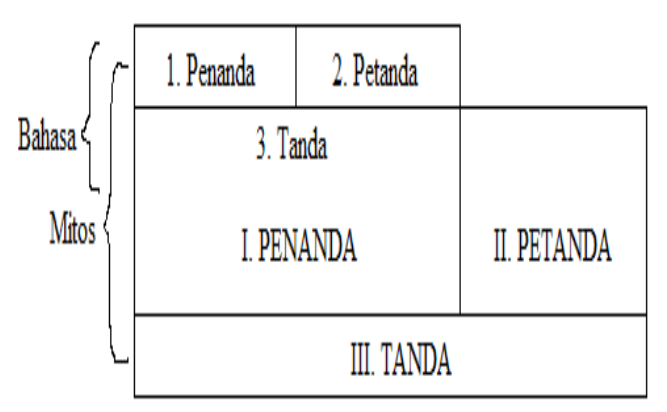

Model Sistem tanda dalam Teori Mitos Barthes (Barthes, 1993: 103) 
Semua hal yang memiliki atau menyampaikan tanda, dapat memproduksi makna. Namun, tidak ada makna yang bersifat tetap. Ia akan berubah dari satu budaya ke budaya lainnya, dari satu periode ke periode lainnya (Hall, 1997: 61). Hall menjelaskan, dalam sistem representasi terdapat tiga pendekatan berbeda, yaitu:

\section{Reflective/mimetic approach}

Dalam pendekatan ini disebutkan bahwa bahasa bekerja secara sederhana, merefleksikan atau meniru kebenaran yang sudah ada sebelumnya dan berfungsi sebagai makna tetap.

2. Intentional approach

Pendekatan yang menyampaikan sebenarnya. Makna yang disampaikan oleh pembicara atau penulis.

3. Constructionist approach

Makna yang dihasilkan adalah makna yang berdasarkan interpretasi atau penafsiran pembaca atau pendengar.

Berdasarkan pemaparan di atas, pendekatan konstruksionis akan digunakan dalam penelitian ini, karena makna yang dihasilkan merupakan hasil interpretasi pembaca.

Iklan-iklan kosmetik ini menggambarkan pencitraan tampilan produk, latar tempat, duta iklan berjenis kelamin laki-laki dan unsur-unsur lainnya. Duta iklan tersebut dianggap mewakili dari kecantikan ideal. Dari elemen-elemen tersebut menghadirkan kembali sosok maskulinitas baru yang diwakili oleh Korea. Dalam menganalisis masalah maskulinitas, dibutuhkan teori gender dan teori mengenai konsep maskulinitas.

\section{HASIL DAN BAHASAN}

Pemaparan dari masing-masing pembacaan iklan menunjukkan konstruksi maskulinitas yang dihadirkan dalam produk kecantikan Korea. Analisis pada masing-masing iklan juga menunjukkan representasi laki-laki baru yang bertujuan untuk mendorong perempuan maupun lakilaki untuk menggunakan kosmetik atau produk kecantikan.

\section{Penjelasan umum tentang produk Etude house dan Tonymoly}

Etude House adalah merek kosmetik Korea yang menawarkan beragam produk perawatan kulit dan makeup. Etude mempunyai empat konsep dasar yaitu kualitas terbaik, harga terjangkau, desain yang cantik dan beragam varian warna menarik. Nama merek Etude terinspirasi dari judul instrumen musik ciptaan komposer Polandia bernama Frederic Chopin. Sudah lebih dari 40 tahun Etude berkonsentrasi di bidang bisnis kosmetik dan telah dikenal banyak orang di seluruh penjuru dunia. Etude House bekerja sama dengan PT Interkos Jaya Bhakti sebagai solo distributor dan membuka toko pertama di Indonesia tahun 2008 di Jakarta. Hingga saat ini terdapat 32 store Etude House di seluruh Indonesia di antaranya Kota Jakarta, Bekasi, Surabaya, Bandung, Medan, Palembang, Semarang, Menado, Bali, Kalimantan.

TonyMoly merupakan merek produk kecantikan Korea yang dispesialisasi dalam mencerahkan kulit dan mengurangi kerutan pada kulit. TonyMoly hadir untuk kebutuhan masyarakat modern, melalui serangkaian produk yang dihasilkan dari teknologi tinggi dan riset yang berkelanjutan. TonyMoly didirikan pada tahun 2006, dengan dukungan dari perusahaan Tae Sung Industry co. Nama TonyMoly berasal dari 2 kata yaitu, kombinasi kata bahasa Inggris 'Tony' yang berarti Stylish, dan kata bahasa Jepang 'Moly' yang berarti 'To Package'. Dengan demikian kombinasi kata TonyMoly, mengandung arti 'mengemas gaya dalam bentuk paket'.

\section{Makna Denotasi dan Konotasi dari Iklan Etude House}

Secara denotatif, gambar 1 menunjukkan tim sepak bola, terdiri dari lima orang laki-laki yang menggunakan seragam bola motif garis-garis berwarna putih-pink, kaos kaki berwarna pink sedang berjaga di depan gawang. Terlihat fokus kamera terhadap bola dan kaki. 
Kemudian, mereka mengaplikasikan $B B$ cream merek Etude House pada wajahnya dengan mulut terbuka dan wajah mereka terlihat lebih jelas bahwa mereka memiliki kulit yang putih, bermata sipit dan berambut warna-warni. Lalu, tim berkaos pink yang menggunakan $\mathrm{BB}$ cream ini menolehkan wajahnya dan tersenyum kepada pemain lawan berkaos biru yang mau menendang bola menuju gawang. Kemudian dimunculkan pencahayaan, terhadap pemain berkaos biru. Pemain berkaos biru berkulit putih, berrambut coklat, berhidung besar dan mancung sedang mengernyitkan dahinya, menutup sedikit matanya dan menutup wajahnya dengan kedua lengannya. Lalu pemain yang mau menendang bola tersebut terlentang di atas lapangan bola. Setelah itu tim beratribut pink berlompat-lompat di atas rumput hijau, mulut mereka terbuka membentuk huruf ' $O$ ', sambil mengangkat kedua tangannya keatas dan telapak tangan yang dikepalkan.

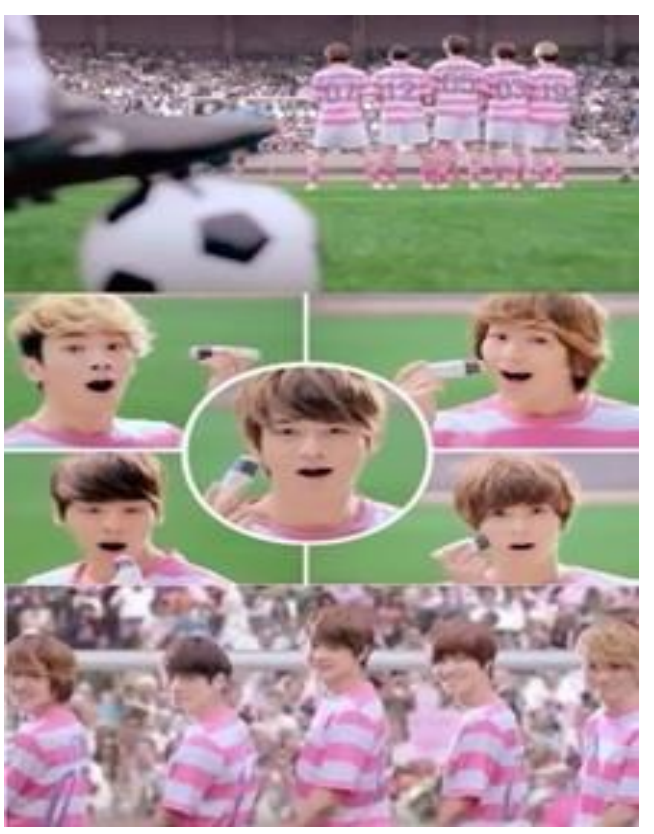

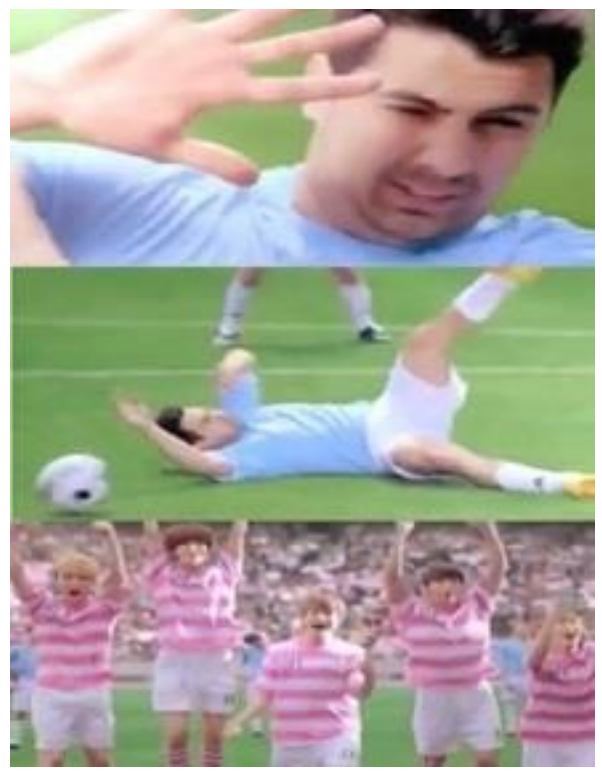

Gambar 1. Iklan produk Etude House BB cream cool skin world championship - 2012 Sumber: www.youtube.com

Secara konotasi, tim yang sedang berjaga di depan gawang menunjukkan kesan maskulin dengan mengenakan seragam bola, sekaligus feminin karena mengenakan atribut berwarna pink. Secara normatif warna pink adalah warna parempuan. Sebagaimana menurut Yulius (2015), persepsi warna merah muda sebagai warna feminin dan warna biru sebagai warna maskulin di mulai sejak perang dunia II. Warna pink dianggap secara normatif sebagai warna perempuan, contohnya saja ketika bayi baru lahir biasanya penanda yang diberikan oleh bidan/rumah sakit bersalin berupa gelang plastik. Jika bayi tersebut berjenis kelamin laki-laki maka akan dikenakan gelang plastik berwarna biru, sedangkan bayi berjenis kelamin perempuan akan dipakaikan gelang berwarna pink. Pada akhirnya, menggunakan pakaian atau atribut berwarna pink, ketika digunakan oleh laki-laki berpengaruh pada citranya, yaitu laki-laki feminin. 
Kemudian bola dan kaki sebagai fokus dari kamera, menunjukkan bahwa ada pemain lawan yang berusaha memasukkan bola ke gawang. Ketika tim beratribut pink mengaplikasikan BB cream pada wajahnya, mereka membuka mulutnya, hal ini menunjukkan ekspresi heran, takjub dan percaya diri. Kemudian ketika mereka menoleh, pemain lawan berkaos biru mengernyitkan dahi dan menutup wajahnya, karena melihat sinar wajah tim beratribut pink yang menoleh. Ekspresi tersebut menunjukkan bahwa pemain berkaos biru merasa silau sehingga terjatuh di atas lapangan. Makna yang dihasilkan dari terjatuhnya pemain berkaos biru adalah kegagalan permain tersebut memasukkan bola ke gawang tim beratribut pink. Tim beratribut pink berlompat-lompat sambil mengangkat tangannya dengan mulut yang membentuk huruf 'O", memiliki makna tersirat bahwa mereka mengekspresikan kebahagiaan dengan berteriak-teriak karena menang dan pemain berkaos biru kalah dalam pertandingan sepak bola. Ketika rumput hijau diperlihatkan pada iklan, hal itu memperjelas bahwa mereka sedang berada di lapangan, sebagai elemen yang memperkuat kejadian yang sedang berlangsung. Dengan atribut sepak bola yang dikenakan mereka, lebih memperjelas bahwa yang mereka menangkan adalah pertandingan sepak bola. Hal ini menunjukkan bahwa laki-laki yang menggunakan kosmetik, laki-laki tampan yang cantik, yang memiliki nilai-nilai feminin tidak teropresi dengan laki-laki maskulin (yang direpresentasikan pemain lawan berkaos biru) yang identik dengan dominasi dan kekuasaan.

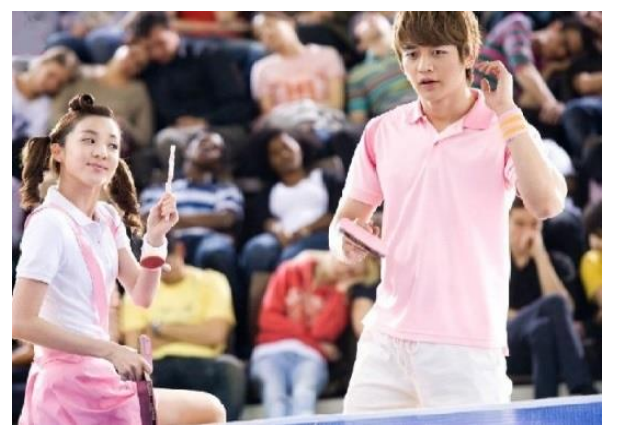

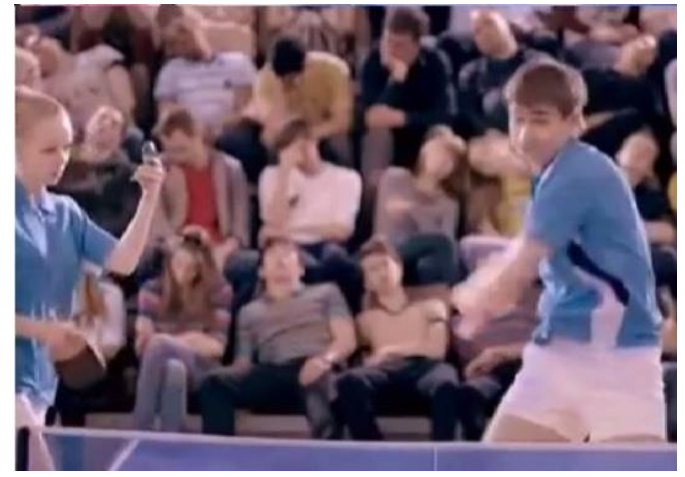

Gambar 2. Iklan produk Etude House BB cream cool skin world championship - 2012 Sumber: www.youtube.com

Secara denotatif, gambar 2 menampilkan latar para penonton yang tertidur ketika menyaksikan suatu pertandingan. Terdapat dua pasang pemain, yaitu pasangan berbaju sport berwarna pink melawan pasangan berbaju sport berwarna biru. Pada gambar tersebut terlihat meja tenis dan pemain yang sedang memegang bat tenis meja. Hal tersebut menunjukkan bahwa mereka sedang bermain tenis meja. Dari gambar tersebut, terlihat bahwa pasangan atlet berbaju pink memiliki mata sipit dan berkulit dan pasangan atlet berbaju biru memiliki rambut pirang kecoklatan dan bermata besar. Laki-laki berbaju pink terlihat sedang merapikan rambutnya sambil membuka sedikit mulutnya dan perempuan berbaju pink sedang mengaca sambil duduk di atas papan meja tenis. Sedangkan laki-laki berbaju biru sedang memukul bola dengan ekspresi wajah yang serius dan perempuan berbaju biru sedang mengaca dengan bedak compact-nya (kemasan bedak yang lengkap dengan kaca dan spons bedak) dengan ekspresi kawatir.

Secara konotatif, pertandingan tenis bola yang merupakan olahraga yang merupakan ranah maskulin. Kemudian, pasangan pemain berbaju sport berwarna pink dan pasangan pemain berbaju sport berwarna biru direpresentasikan sebagai feminin dan maskulin. Pasangan berbaju pink menggunakan kosmetik BB cream dari Etude House sehingga meskipun 
bermain tenis meja di musim panas, mereka tetap terlihat tampan dan cantik. Perempuan berbaju biru yang tidak menggunakan $\mathrm{BB}$ cream terlihat kawatir akan penampilannya, sehingga dia tidak fokus pada permainan. Laki-laki berbaju biru menunjukkan ekspresi serius dan terihat lelah dalam permainan. Hal ini menunjukkan pesan tersirat bahwa untuk menjadi maskulin yang ideal itu tidak luwes dan melelahkan. Penggambaran laki-laki yang sedang memukul bola sambil membuka sedikit mulutnya lalu merapikan rambutnya menunjukkan ekspresi sensual untuk menunjukkan ketampanannya dan rasa percaya diri. Hal ini mempertegas bahwa meskipun olahraga ranah maskulin, iklan ini menyodorkan pesan bahwa atlet juga perlu menjaga penampilan.

Selain itu, mata sipit dan kulit putih menunjukkan ras mongoloid pada pemain berbaju pink. Mata besar dan rambut pirang pada pemain berbaju biru, merepresentasikan ras kaukasoid. Ras yang direpresentasikan pada iklan ini, yaitu Asia dan Barat, menunjukkan resistensi Asia terhadap andil kekuasaan kulit putih mengenai maskulinitas. Sebagaimana menurut Chapman (1988), meski tidak terucap, hanya subjek kulit putih lah yang memiliki pengetahuan mengenai representasi realitas. Sehingga standar maskulinitas yang dibentuk oleh kulit putih menjadi maskulinitas hegemonik yang dianggap nyata. Tetapi, iklan ini menunjukkan bahwa orang Asia lebih cair mengenai masalah gender dan percaya diri dengan maskulinitasnya yang berbeda dengan maskulinitas hegemonik.

Secara denotatif, pada gambar 3 terdapat laki-laki memakai kaos berkerah berwarna pink, gelang rantai berwarna perak dan handband berwarna pastel. Lakilaki berkalung medali emas ini sedang memegang medali emasnya dan produk Etude House BB cream cool skin. Laki-laki tersebut membuka mulutnya dan giginya terlihat.

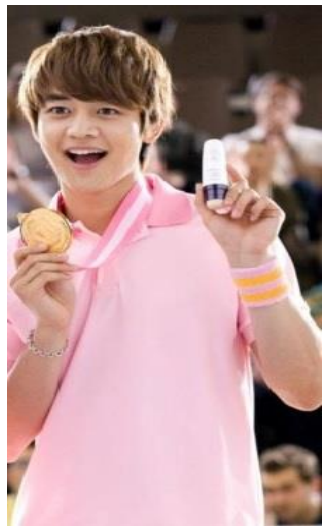

Gambar 3. Iklan produk Etude House BB cream cool skin world championship - 2012 Sumber: www.youtube.com

Pada tataran konotasi, dengan gaya berpakaian laki-laki yang ditampilkan pada gambar 3, dapat diinterpretasikan bahwa laki-laki ini berprofesi sebagai atlet olahraga. Hal ini menunjukkan kemaskulinan dari sosok laki-laki ini. Akan tetapi, gelang perak, handband berwarna pastel, serta kaos berkerah pink menunjukkan esensi feminin dari laki-laki tersebut. Hal tersebut dikarenakan gelang merupakan aksesoris perempuan, serta warna pastel pada handband adalah warna feminin, karena merupakan warna yang lembut. Medali emas yang dikalungkan dilehernya, menunjukkan kemenangannya sebagai atlet. Medali emas yang dipegangnya merupakan bentuk dari kebanggaannya dan rasa percaya diri, serta produk yang dipegangnya bermakna lakilaki juga perlu kosmetik dalam meraih kemenangan. Laki-laki tersebut menunjukkan rasa senangnya dengan ekspresif, terlihat dari wajah tersenyumnya dengan mulut yang terbuka dan gigi yang terlihat. Hal ini menunjukkan bahwa lakilaki maskulin beratribut feminin mampu meraih kesuksesan.

Secara denotatif, pada gambar 4 terdapat 3 sosok laki-laki yang sedang tersenyum serta membuat bentuk hati dengan tangannya. Ketiga bibir laki-laki ini berwarna pink pucat. Laki-laki pertama memakai kacamata berbingkai bulat, berrambut hitam mengkilat yang dibelah pinggir dengan rapi, berkemeja garis-garis 
putih dan pink, serta memakai syal pink bermotif polkadot putih. Laki-laki kedua memakai anting berwarna hitam, berkemeja putih dipadukan dengan rompi berwarna biru muda dengan gaya rambut spike berwarna coklat. Laki-laki ketiga memakai kemeja bermotif garis putih-biru, syal biru bermotif polkadot putih dan berrambut hitam mengkilat yang dibelah pinggir dengan sedikit gelombang pada bagian depan rambutnya. Dibelakang mereka terdapat pintu berwarna pink, jam dinding, bingkai foto, lampu, vas bunga serta perabot lain yang di dominasi dengan warna pink, putih dan biru muda.

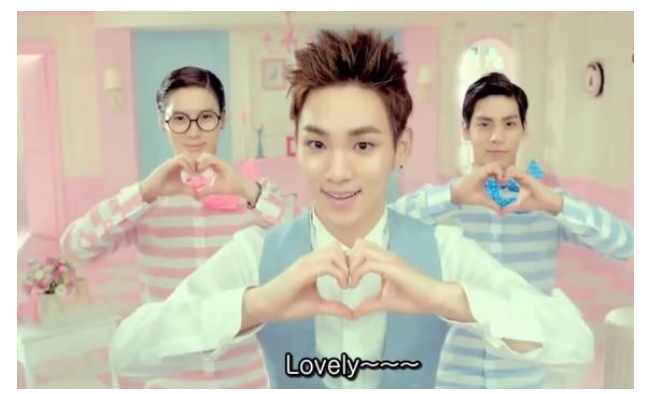

Gambar 4. Iklan produk Etude House eyelash perm 3 step volumecara - 2012

Sumber: www.youtube.com

Secara konotatif, tiga sosok laki-laki pada gambar 4 terlihat sangat mementingkan gaya berpakaian, riasan wajah dan model rambut. Hal tersebut dapat dilihat dengan warna bibir ketiga laki-laki tersebut berwarna pink pucat, yang berarti laki-laki tersebut menggunakan pewarna bibir atau lipstik. Rambut hitam mengkilat pada laki-laki pertama dan ketiga, menunjukkan bahwa kedua laki-laki ini memakai minyak rambut atau gel rambut untuk merapikan rambutnya. Sedangkan laki-laki kedua menggunakan gel rambut agar rambutnya bisa berdiri ke atas. Pakaian yang dikenakan ketiga laki-laki pada gambar 4 terlihat chic. Melalui pemaknaan secara konotatif ini menunjukkan bahwa ketiga laki-laki ini mementingkan penampilannya. Ketiga laki-laki tersebut sedang berada di rumah (indoor), dapat diketahui dengan latar tempat ketiga laki- laki tersebut yang berisi pintu, jendela, vas bunga, bingkai foto, dan perabot lainnya. Citra maskulin laki-laki ditunjukkan dengan kebebasan, aktivitasnya di luar (outdoor), sedangkan ranah indoor merupakan area aktivitas perempuan. Kemudian, perabot yang didominasi warna pink, putih dan biru muda menunjukkan warna feminin karenawarna-warna tersebut dikategorikan sebagai warna terang. Menurut Khouw (2007), warna feminin lebih cenderung terhadap warna-warna cerah terang dan colorful [banyak warna]. Kategori laki-laki ini disebut laki-laki metroseksual, sebagaimana menurut Flocker (2003), mereka [laki-laki metroseksual] berusaha berpenampilan sempurna, bagaimana melakukan perawatan kulit, menata rambut, termasuk hal-hal yang direkomendasikan dan hal-hal yang tabu agar bisa tampil menarik.

Secara denotatif, gambar 5 menampilkan kumpulan laki-laki yang sedang berdiri sambil berlompat-lompat. Mereka mengangkat spons bedak dari produk Etude House versi ukuran besar dengan kedua. Beberapa laki-laki memperlihatkan giginya dan beberapa lakilaki terlihat sedang menyunggingkan bibirnya. Kumpulan laki-laki tersebut memakai pakaian yang sama. Mereka mengenakan kostum serba putih, yaitu, celana panjang putih, sepatu putih tuxedo berwarna putih serta mengenakan kemeja pink di dalamnya.

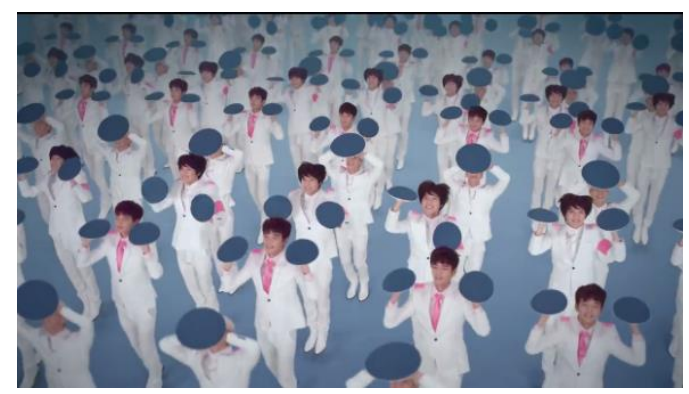

Gambar 5. Iklan produk Etude House bedak precious mineral any cushion - 2013

Sumber: www.youtube.com

Secara konotatif, atribut serba putih yang dikenakan kumpulan laki-laki pada gambar 5 merepresentasikan laki-laki 
feminin, karena warna putih yang merupakan oposisi biner dari warna hitam, yang mana warna hitam merupakan warna maskulin. Sebagai contoh, dalam upacara pernikahan beberapa negara, pengantin laki-laki mengenakan tuxedo atau jas serba hitam dan pengantin perempuan mengenakan gaun berwarna putih. Makna dari kemeja pink yang dikenakan mereka lebih menonjolkan esensi feminin. Kumpulan laki-laki yang terlihat sedang berjinjit, sedang berlompat-lompat sambil mengangkat-angkat spons bedak merek Etude House menunjukkan bahwa mereka sedang mengagung-agungkan spons bedak yang merupakan bagian dari produk yang sedang diiklankan. Hal tersebut dapat dilihat dari spons berukuran besar. Secara keseluruhan, gambar tersebut memiliki makna tersirat bahwa kumpulan laki-laki tersebut mengajak massa bergender maskulin untuk menggunakan kosmetik.

Secara denotatif, gambar 6 menampilkan laki-laki dewasa, berkumis tipis, berjanggut tipis dan memiliki rambut hitam semu coklat tua sedang tersenyum. Laki-laki ini juga berkulit agak gelap serta mengenakan kemeja putih yang dilapisi celemek berwarna pink bermotif polkadot, sedang memegang salah satu produk kecantikan Etude House, yaitu bedak Morning Any Cushion Crem Filter dengan tangan kanannya. Tangan kirinya membentuk sebuah ikon dengan jari jempol dan telunjuknya. Kemudian dia mengaplikasikan bedak merek Etude House tersebut dengan cara memukulmukulkan spons bedak pada wajahnya.

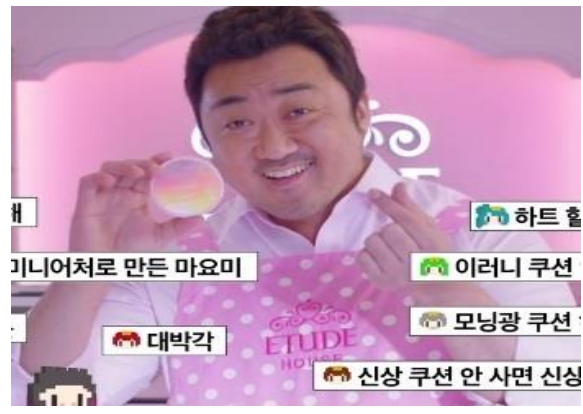

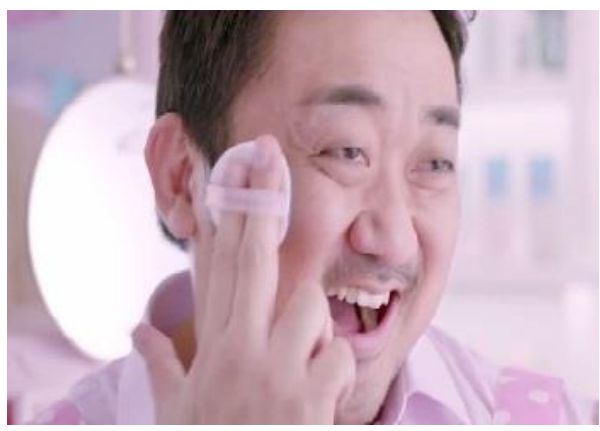

Gambar 6. Iklan produk Etude House Morning Any Cushion Crem Filter - 2016

Sumber: www.youtube.com

Secara konotatif, laki-laki paruh baya, berkumis tipis, berkulit gelap dan berjanggut tipis menunjukkan sosok lakilaki maskulin yang ideal, karena tidak terlihat seperti laki-laki yang merawat diri. Karena merawat diri digenderkan terhadap perempuan. Tetapi dengan celemek pink bermotif polkadot sambil memegang bedak, esensi maskulinitasnya menjadi kusut. Kekusutan maskulinitasnya dikarenakan dua hal, yaitu cara memegang bedak yang secara tersirat sebagai ajakan memakai bedak, padahal bedak adalah atribut kecantikan, berarti merupakan ranah feminin. Lalu, celemek biasanya digunakan ketika memasak. Masak merupakan pekerjaan domestik yang selalu dikaitkan dengan perempuan sehingga celemek juga merupakan atribut feminin.

Laki-laki dengan perawakan dan postur tubuh seperti pada gambar 6, terlihat seperti laki-laki paruh baya, yang merepresentasikan sosok seorang bapak. Iklan ini menunjukkan bahwa kosmetik tidak hanya untuk laki-laki muda, tetapi laki-laki paruh baya pun diajak untuk menggunakan kosmetik. Senyuman yang diekspresikan oleh laki-laki paruh baya tersebut merepresentasikan sosok bapak yang baru, meruntuhkan nilai-nilai maskulinitas sosok bapak, yang harusnya tegas, serius, otoriter, membentengi lakilaki atau sosok bapak untuk masuk ke ranah domestik.

Laki-laki pada gambar 6 juga membentuk jari jempol dan jari telunjuk 
pada tangan kirinya dengan suatu ikon ${ }^{1}$. Ikon tersebut, dalam kebudayaan Korea disebut harte (pengucapan orang Korea pada istilah bahasa Inggris heart) yang bermakna cinta. Oleh karena itu, laki-laki tersebut mengekspresikan rasa cintanya dengan menbentuk ikon tersebut dengan tangannya. Laki-laki maskulin tidak menunjukkan ekspresinya dan cenderung tertutup, sebagaimana menurut Metcaf dan Humphries (dikutip oleh Nixon, 1997: 296), maskulinitas memiliki karakter yang keras/kasar, berjiwa kompetitif, cenderung emosional dan dingin, serta menjaga jarak terhadap hubungan emosi terhadap ayah maupun pasangan. Meskipun memakai kosmetik bedak adalah ranah feminin, lakilaki ini memakai bedak dengan memukulmukulkan spons pada wajahnya agar gestur tubuhnya tetap terlihat macho dan tidak sissy. Padahal menurut Brannon dan David (1976), segala sesuatu yang feminin bahkan sekecil apa pun yang menunjukkan femininitas terlarang untuk dapat membuktikan maskulinitas. Seorang lakilaki sejati harus menghindari segala kelakuan atau karakteristik yang berhubungan dengan perempuan. Tetapi ketika melihat iklan yang dianalisis, konstruksi sosial mengenai laki-laki yang dijelaskan oleh Brannon tidaklah benar dan justru melepaskan mitos maskulinitas.

Secara denotatif, gambar 7 masih menunjukkan laki-laki pada gambar 6 . Tetapi, pada gambar 7 ini laki-laki ini mengepalkan kedua telapak tangannya, kemudian menaruh kedua tangannya tersebut didekat kedua pipinya, lalu kedua tangannya digoyangkan ke depan dan kebelakang.

Secara konotatif, gerakan tersebut merupakan salah satu gerakan aegyo dalam

\footnotetext{
${ }^{1}$ Pierce mencirikan ikon sebagai suatu tanda yang menggantikan sesuatu semata-mata karena mirip, sebagai suatu tanda yang mengambil bagian dalam karakter-karakter objek; atau sebagai suatu tanda yang kualitasnya mencerminkan objeknya, membangkitkan sensasi-sensasi analog di dalam benak lantaran kemiripannya. (Budiman, 2005:62).
}

budaya Korea. Aegyo merupakan gestur dan gaya ucapan dalam budaya Korea yang biasanya dilakukan oleh anak-anak atau remaja perempuan agar terlihat imut atau lucu di mata orang lain. Pada gambar 7, meskipun laki-laki paruh baya ini melakukan gerakan Aegyo, tidak membuatnya terlihat seperti banci, tetapi terlihat ramah tanpa mengurangi nilai kejantanan dari fisiknya.

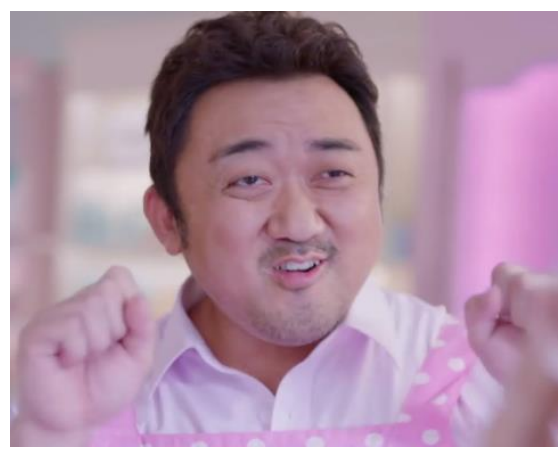

Gambar 7. Iklan produk Etude House Morning Any Cushion Crem Filter - 2016 Sumber: www.youtube.com

\section{Makna Denotasi dan Konotasi dari Iklan TonyMoly}

Menurut tataran denotasi, terdapat beberapa cuplikan iklan pada gambar 8 . Pada iklan tersebut, terlihat seorang lakilaki bertopi jenis porkpie, mengenakan kardigan berwarna krem dan celana hitam, serta berrambut hitam dengan poni kesamping, sedang memegang kamera, sambil menyender pada sebuah mobil. Laki-laki yang sama, dengan pakaian berbeda, sedang memotret seorang perempuan. Laki-laki tersebut memakai kemeja berbahan denim berwarna biru, serta memakai jam tangan dari bahan logam. Kemudian, laki-laki tersebut memakai syal berwarna coklat motif, sambil memegang bibirnya dengan tangan kanannya, sambil meperlihatkan giginya dan menyunggingkan senyum. 


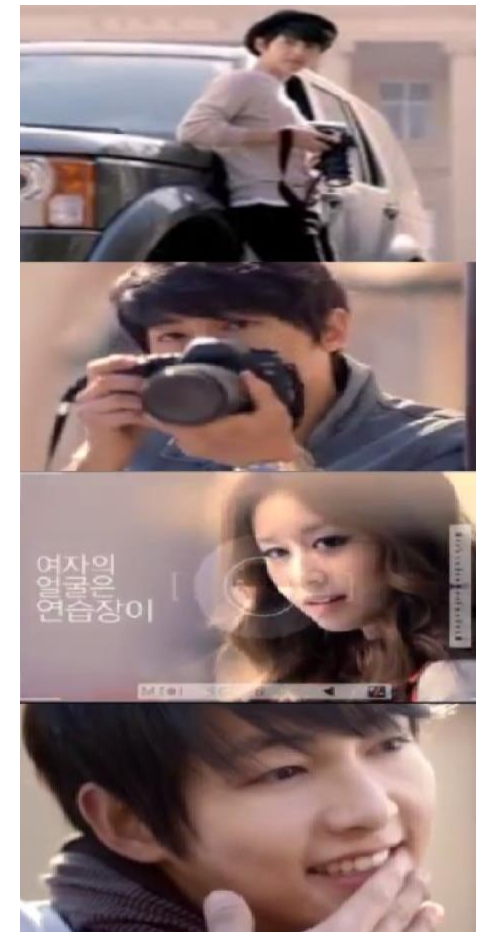

Gambar 8. Iklan produk TonyMoly Floria whitening capsule essence - 2012

Sumber: www.youtube.com

Secara konotatif, laki-laki yang sama dengan pakaian berbeda pada gambar 8, menunjukkan bahwa iklan tersebut menampilkan aktivitas laki-laki tersebut dalam kurun waktu beberapa hari. Pada hari pertama laki-laki tersebut memakai topi porkpie, menunjukkan bahwa laki-laki tersebut menjaga penampilannya, karena topi porkpie biasanya digunakan oleh orang yang mengerti fashion. Warna krem dan hitam pada pakaiannya merupakan warna maskulin. Pada hari berikutnya, laki-laki tersebut memakai kemeja denim, dengan warna biru yang merupakan warna maskulin. Kemudian pada hari selanjutnya laki-laki tersebut memakai syal bermotif coklat, coklat juga merupakan warna maskulin karena cenderung gelap. Gaya rambut laki-laki ini menampilkan kesan rapi dengan poni teratur yang tersisir ke samping. Dari cara berpakaian dan gaya rambut, menunjukkan bahwa laki-laki tersebut merupakan representasi dari lakilaki metroseksual. Kemudian, mobil dan jam tangan dari metal menunjukkan kesuksesan dari laki-laki tersebut. Karena mobil dan jam tangan metal merupakan barang tersier. Hal tersebut menunjukkan kelas sosial, bahwa laki-laki tersebut berada di kelas menengah ke atas.

Pada gambar tesebut terlihat bahwa laki-laki tersebut sedang menguntit seorang perempuan. Hal tersebut dapat terlihat dengan kamera yang dibawanya dan cara dia memotret secara sembunyisembunyi. Perempuan pada gambar 8 memiliki rambut berwarna coklat dan bergelombang, berkulit putih, berhidung mancung, bermata tajam dan bibir berwarna pink. Dengan ciri-ciri tersebut, perempuan tersebut direpresentasikan sebagai perempuan yang cantik. Perempuan yang menjadi objek kamera, menunjukkan adanya konsep male gaze pada iklan tersebut. Menurut Mulvey (1973), konsep male gaze dalam industri sinematografi, yang menurutnya terlalu menggunakan pandangan laki-laki. Perempuan sendiri tidak diposisikan sebagai subyek yang punya kuasa atas dirinya sendiri (self-possessiveness) melainkan sebagai objek dari male gaze. Mata dari sebuah kamera pun diibaratkan sebagai mata seorang laki-laki sehingga tampilan perempuan di dalam media cenderung tunduk pada kontrol tatapan mata laki-laki. Pesan yang ada dalam film dipengaruhi oleh laki-laki yang kemudian disampaikan pada penonton, sementara perempuan hanya menjadi tontonan. Hal tersebut terlihat dari senyum laki-laki yang terdapat pada cuplikan terakhir pada gambar 8. Laki-laki tersebut tersenyum sambil memegang bibirnya dengan tangan kanannya, memiliki makna bahwa laki-laki tersebut merasa puas memandangi perempuan cantik tadi. Selain itu, senyuman laki-laki tersebut juga memiliki makna kekaguman laki-laki terhadap kecantikan perempuan. Jadi, meskipun perempuan tersebut menjadi objek, tapi secara positif, perempuan tersebut tidak teropresi dengan male gaze, yang melihat perempuan sebagai objek seksual. Selain itu, iklan tersebut juga menyampaikan pesan tersirat bahwa laki-laki yang 
memperhatikan penampilannya bukan lah laki-laki gay, karena dia tertarik pada perempuan. Hal ini menjelaskan bahwa gender tidak berkaitan dengan orientasi seksual seseorang.

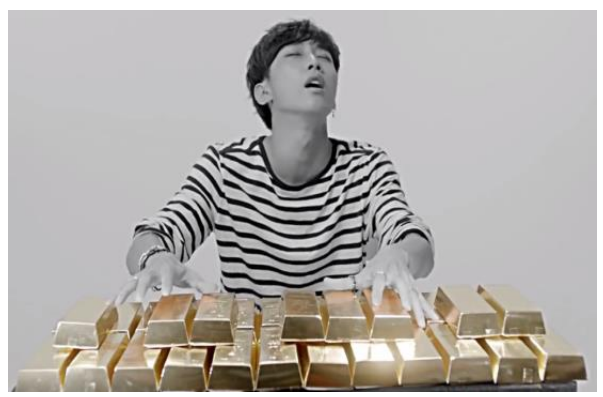

Gambar 9. Iklan produk TonyMoly Gold $24 K$ Mask "gold melody" - 2014 Sumber: www.youtube.com

Secara denotatif, gambar 9 menampilkan laki-laki yang memakai kaos tanpa kerah berlengan panjang, bermotif garis hitam dan putih serta memakai gelang berwarna hitam dipergelangan tangannya. Laki-laki tersebut menghadap keatas dengan mata terpejam dengan mulut terbuka. Kemudian, terdapat tumpukan kemasan Produk TonyMoly Gold 24K Mask di hadapan laki-laki tersebut. Lalu, tumpukan kemasan produk disentuh dengan jari-jari kedua tangan laki-laki tersebut. Iklan ini menggunakan teknik pewarnaan Grayscale secara keseluruhan, meskipun produk yang diiklankan tetap ditampilkan dengan warna asli, yaitu emas.

Menurut tataran konotasi, laki-laki dengan mata terpejam dan mulut terbuka pada gambar 9 menampilkan ekspresi sedang mencoba merasakan sesuatu. Hal tersebut menunjukkan kesan sensitif pada laki-laki tersebut. Sensitif atau perasa adalah sifat yang distrereotifkan terhadap perempuan. Hal tersebut menunjukkan adanya kesan feminin pada laki-laki tersebut, meskipun atribut berwarna hitam dan putih yang dikenakannya menunjukkan esensi yang maskulin.

Produk TonyMoly Gold 24K Mask yang disusun rapi dihadapan laki-laki tersebut merupakan simbol yang meminjam makna asli benda yang seharusnya piano. Maksudnya piano yang seharusnya disentuh oleh laki-laki pada iklan, digantikan oleh produk TonyMoly tadi. Hal tersebut menunjukkan bahwa laki-laki tersebut berprofesi sebagai pemain piano. Menurut Fakih (2006: 8-9), dalam perspektif gender, maskulin adalah sifat yang melekat pada laki-laki yakni kuat, rasional dan perkasa, sedangkan feminin adalah sifat yang melekat pada perempuan yakni, lemah lembut, emosional dan keibuan. Piano yang ditekan dengan kelembutan oleh laki-laki yang peka dan sensitif, menunjukkan bahwa pemain piano merupakan pekerjaan yang bersifat feminin. Makna tersirat dari penggambaran iklan tersebut, yang mana piano merupakan benda yang sangat penting bagi pemusik, dan produk TonyMoly yang dipinjam sebagai elemen pengganti piano juga sama pentingnya dengan piano bagi pemusik. Representasi laki-laki pada gambar 9 mempersuasikan agar laki-laki yang bekerja sebagai pemusik menggunakan kosmetik atau produk kecantikan. Selain itu, teknik pewarnaan grayscale pada iklan menunjukkan kesan yang maskulin, karena warna abu-abu, warna yang merupakan perpaduan antara warna hitam dan putih, merupakan warna maskulin. Menurut Guilfros dan Smith dikutip oleh Khouw (2007), warna akromatik (hitam, putih dan abu-abu) merupakan warna maskulin. Sehingga, tetap menampilkan elemenelemen maskulin.

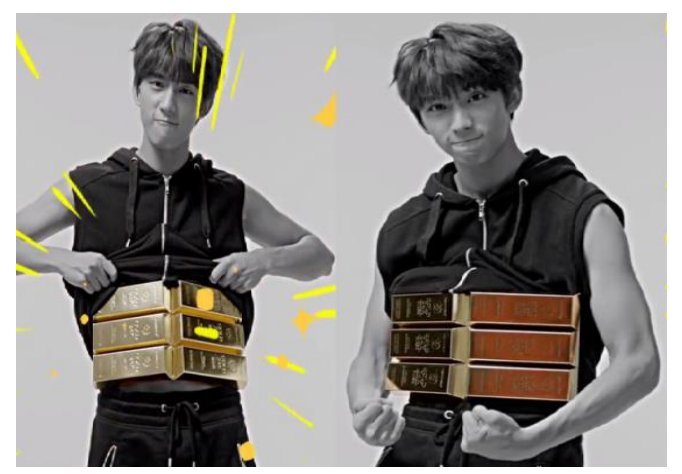

Gambar 10. Iklan produk TonyMoly Gold $24 K$ Mask "gold power" - 2014 Sumber: www.youtube.com 
Secara denotatif, gambar 10 menampilkan laki laki yang berambut berantakan, memakai celana olah raga berwarna hitam, baju hoodie hitam tanpa lengan, bermata tajam dan melipat bibirnya ke dalam mulut. Kemudian dia mengangkat bajunya dan memperlihatkan bagian perut. Pada perutnya terlihat enam kemasan produk TonyMoly Gold $24 K$ Mask. Lalu dia berpose, mengepalkan kedua tangannya dan terlihat bagian lengannya yang berotot.

Secara konotatif, laki-laki atribut hitam dari mulai celana dan hoodie menunjukkan kemaskulinan laki-laki tersebut. Celana olah raga dan Hoodie menunjukkan makna tersirat bahwa lakilaki tersebut berprofesi sebagai atlet. Kemudian, laki-laki ber-hoodie tanpa lengan, dengan sengaja memperlihatkan otot tangannya dengan berpose ala "Ade Ray". Hal tersebut menunjukkan bahwa laki-laki tersebut memiliki kekuatan, perkasa dan jantan. Selain itu, enam kemasan produk TonyMoly Gold $24 \mathrm{~K}$ Mask dipinjam untuk mewakili otot perut six pack laki-laki pada iklan tersebut. Six pack pada bagian perut adalah kebanggaan seorang atlet laki-laki. Kemudian produk yang mengganti penggambaran six pack pada laki-laki tersebut, diinterpretasikan bahwa produk enam kemasan produk TonyMoly Gold $24 K$ Mask merupakan kebanggaan laki-laki atlet sama halnya dengan perut six pack. Hal tersebut menunjukkan laki-laki yang maskulin, yang berotot, macho dan kuat tidak perlu malu dan harus bangga dalam menggunakan produk kecantikan.

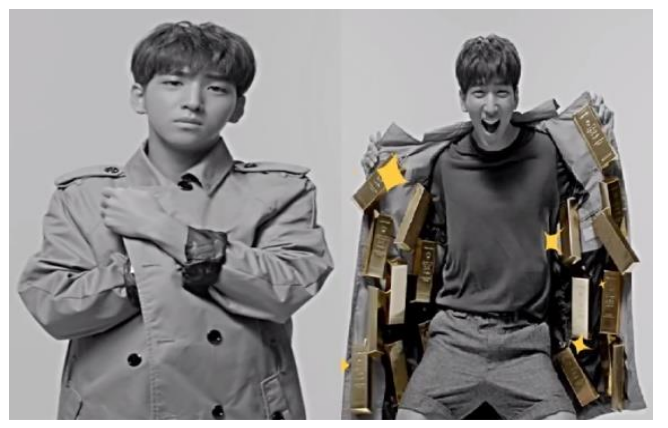

Gambar 11. Iklan produk TonyMoly Gold 24K Mask "gold surprise" - 2014

Sumber: www.youtube.com
Secara denotatif, gambar 11 menampilkan laki-laki yang memakai mantel yang menutup rapat tubuhnya dan tangan yang mencengkram pada mantelnya. Bibir laki-laki tersebut tertutup rapat, mata yang sedikit tertutup dan dahi yang dikernyitkan. Lalu laki-laki tersebut membuka mantelnya sambil menggoyangkan tubuhnya ke kanan dan ke kiri. Pada bagian dalam mantelnya tersebut, tergantung beberapa produk TonyMoly Gold $24 K$ Mask. Di dalam mantelnya, laki-laki tersebut mengenakan kaos polos dan celana pendek. Ketika membuka mantel, laki-laki tersebut membuka mulutnya dan memperlihatkan giginya.

Secara konotatif, laki-laki pada gambar 11 yang menutupi tubuhnya dengan mantel, memiliki ekspresi diam dengan raut wajah yang terlihat sedih. Hal tersebut menunjukkan laki-laki tersebut sedih ketika menutupi tubuhnya. Kemudian, ketika dia membuka mantelnya, dan memperlihatkan beberapa bagian tubuhnya, sekaligus memperlihatkan produk TonyMoly Gold $24 K$ Mask yang tergantung pada mantelnya, laki-laki tersebut menunjukkan ekspresi bahagia dan senang. Sedih dan bahagia yang diekspresikan laki-laki tersebut menunjukkan emosi dari laki-laki tersebut. Sedangkan sifat emosional merupakan sifat yang digenderkan kepada perempuan, yaitu feminin. Salah satu aspek kemaskulininan adalah kendali atau kontrol diri. Tetapi, laki-laki pada gambar tersebut bebas mengekspresikan dirinya dengan menggoyang-goyangkan tubuhnya ke kanan dan ke kiri sambil tertawa lepas. Hal tersebut menunjukkan bahwa laki-laki tersebut tidak memiliki aspek kemaskulinan, yakni kendali atau kontrol diri. Tetapi, laki-laki tersebut tetap terlihat maskulin dengan kaos polos dan celana pendek dengan warna netral.

Tubuh merupakan ranah feminin. Karena laki-laki sebagai subjek male gaze menjadikan tubuh perempuan sebagai objek pandangan laki-laki pada media. 
Pada gambar 11, laki-laki yang terlihat sedih dengan menutup mantelnya, lalu bahagia dengan menunjukkan tubuhnya, hal tersebut memiliki ideologi secara tersirat bahwa laki-laki lebih nyaman di zona maskulinitas modern, yang mana laki-laki tidak harus mengikuti nilai-nilai maskulinitas dominan, yang terkukung dalam bias patriarki.

Secara denotatif, gambar 12 menampilkan laki-laki berkacamata, bermata tajam dan mulut tertutup. Lakilaki tersebut memiliki rambut yang dibelah pinggir dengan rapi. Laki-laki tersebut memakai pakaian formal, jas hitam, kemeja putih, celana hitam dan berdasi. Kemudian dia memegang produk TonyMoly Gold 24K Mask disamping telinganya.

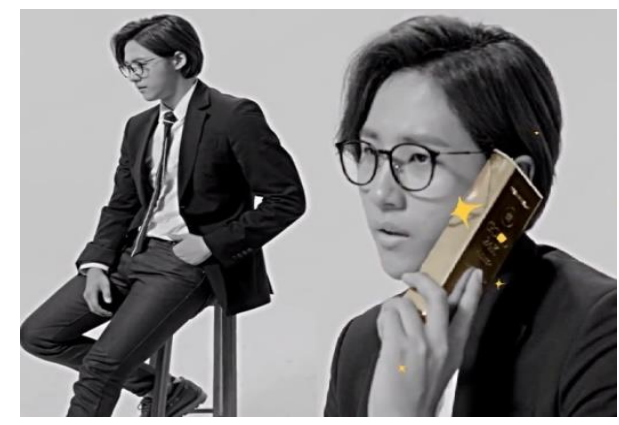

Gambar 12. Iklan produk TonyMoly Gold $24 K$ Mask "gold news" - 2014

Sumber: www.youtube.com

Secara konotatif, pakaian yang dikenakan oleh laki-laki pada gambar 12 menunjukkan bahwa profesi dari laki-laki tersebut adalah pekerja kantoran atau pebisnis (pebisnis). Dari penampilannya, laki-laki ini terlihat dandy dengan gayanya yang konservatif. Kemudian, tatapannya yang tajam menunjukkan ekspresi serius, memiliki makna bungkam dan tidak ekspresif dan terlihat memiliki kontrol diri. Nilai-nilai tersebut menunjukkan kemaskulinannya. Pekerja kantoran biasanya tidak lepas dari telefon seluler karena kesibukannya dengan relasi bisnisnya. Benda pentingnya untuk menjadi sukses, yaitu telefon seluler, diganti dengan dihadirkannya produk
TonyMoly Gold 24K Mask yang ditempelkan di dekat telinganya. Hal tersebut diinterpretasikan bahwa produk TonyMoly tersebut sama pentingnya dengan telefon genggam bagi pebisnis. Iklan ini mengajak laki-laki pekerja yang merupakan representasi dari laki-laki maskulin ideal, agar menggunakan produk kecantikan serta merawat ketampanan wajahnya.

\section{PENUTUP}

Maskulinitas dan femininitas seseorang tidak dapat ditetapkan berdasarkan seks, laki-laki dan perempuan, tetapi sesuatu yang dilakukan oleh seseorang menjadi hasil dari gender. Hegemoni dipandang sebagai pertentangan dari relasi sosial yang ada. Hegemoni merupakan ideologi yang dominan dan berpengaruh terhadap sebuah teks. Teks, salah satunya iklan, tidak bersifat mutlak dan dapat dilawan, dinegosiasikan sesuai lingkup sosial pembacanya. Iklan dari dua merek kosmetik Korea menampilkan berbagai konsep maskulinitas, berusaha untuk memengaruhi masyarakat, serta mempersuasi agar laki-laki perlu untuk merawat diri dan memperhatikan penampilannya. Selain itu, laki-laki yang ditampilkan dari dua merek kosmetik Korea ini, merupakan pembantahan akan konsep male gaze, yang dibentuk oleh bias patriarki, yang mana tubuh perempuan menjadi objek erotik pandangan laki-laki dalam teks atau media. Iklan-iklan ini menunjukkan bahwa konsep tersebut mulai bergeser, dengan munculnya reversal gaze atau female gaze yang direpresentasikan oleh sosok laki-laki pada iklan-iklan tersebut. Dengan munculnya laki-laki yang memiliki nilai femininitas pada iklan, serta terjualnya dan diidolakannya laki-laki yang direpresentasikan dalam iklan, menunjukkan bahwa laki-laki yang memiliki nilai-nilai maskulinitas baru tersebut meresistensi nilai-nilai maskulinitas hegemonik. 


\section{DAFTAR SUMBER}

\section{Jurnal}

Mulfey, Laura. "Visual Pleasure and Narrative Cinema”. Screen. Oxford Journals. 16 (3): 6-18. doi:10.1093/screen/16.3.6. UK, musim gugur, 1973.

\section{Buku}

Budiman, Kris. 2005.

Ikonisitas: Semiotika Sastra Dan Seni Visual. Yogyakarta: Buku Baik.

Butler, Judith. 1990.

Gender Trouble: Feminism and the Subversion of Identity. United States of America: Routledge.

Barker, Chris. 2000.

Cultural Studies: Practice and Theory. London: Sagr Publications Ltd.

Barthes, Roland. 1993. Mythologies. Jonathan Cape (terj.). New York: The Noonday Press.

Beynon, John. 2002. Maskulinities and Cultures. Buckingham, UK: Open University Press.

Chapman, Rowena dan Jonathan Rutherford. 1988.

Male Order Unwrapping Masculinity. London: Lawrence \& Wishart Ltd.

Connel, Raewyn. 2000.

The Men and the Boys. California: Allen \& Unwin.

Cornwall, A. and N. Lindisfarne. 1994. Dislocating Masculinity: Comparative Ethnographies, United States of America: Routledge.

David, D. S. and R. Brannon. 1976.

The Forty-nine percent majority: the male sex role. Addison-Wesley Pub. Co.

Feasey, R. 2008.

Masculinity and Popular Television, Edinburgh: University Press.

Flocker, M. 2003.

The Metrosexual Guide To Style: A Handbook For The Modern Man. Da Capo Press.

Hall, Stuart. 1997.

Representation: Cultural

Representations and Signifying
Practices. Ed. Stuart Hall. London:

Sage/The Open University, 1997

Hoed, Benny H. 2011.

Semiotik \& Dinamika Sosial Budaya.

Depo: Komunitas Bambu, 2011.

Liliweri, Alo. 1992.

Dasar-dasar Komunikasi Periklanan. PT. Citra Aditya Bakti.

Nixon, Sean. 1997.

Exhibiting Masculinity Representation: Cultural Representations and Signifying Practices. Ed. Stuart Hall. London: Sage/The Open University.

Ostergaard, Lise. 1997.

Gender and development: a practical guide. United States of Americ: Routledge.

Otnes, C. and L. Tuncay-Zayer. 2012.

Gender, Culture, and Consumer Behavior. United States of America: Routledge.

Piliang, Yasraf Amir. 1998

Sebuah Dunia yang Dilipat: Realitas Kebudayaan Menjelang Milenium Ketiga dan Matinya Posmodernisme, Penerbit Mizan.

Yulius, Henry. 2015.

Coming Out. Jakarta: Kepustakaan Populer Gramedia

\section{Internet}

Wardani, Alien Nuril.Pengertian Korean Wave / Hallyu. Diakses dari http://aliennwardani.blogspot.co.id/201 3/03/pengertian-korean-wavehallyu.html, Tanggal 18 Maret 2017 Pukul 20.00 WIB.

Khouw, Nathalie. The Meaning of Color for Gender. Diakses dari http://www.colormatters.com/colorsymbolism/gender-differences, Tanggal 29 Maret 2017 pukul 12.00 WIB 